\title{
PREFERENCE OF BIOMPHALARIA TENAGOPHILA AMONG MACROPHYTES AND THEIR PERIPHYTONS DETERMINED THROUGH THE DEGREE OF ATTRACTIVENESS
}

Mairy Barbosa Loureiro dos SANTOS (1) \& José Rabelo de FREITAS (1)

\section{S U M M A R $\mathbf{Y}$}

In presence of extracts of six flowering plants the Biomphalaria tenagophila was more attracted to four them in the following sequence: Nasturtium pumilum $>$ Polygonum acre $>$ Commelina $s p$. = Echinochloa crusgalli. The periphyton of these flowering plants attracted in the same way the B. tenagophila but without no preference for either of them. Reporting the results that behavior may be evalua ted as a co-evolution between snail and plants.

KEY WORDS: Biomphalaria tenagophila; Macrophytes; Periphyton.

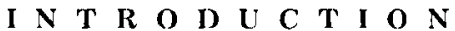

In ecological approaches to the feeding be havior of animals, prominence is given to their ability to spot the food in an attempt to maxi mize the gain in energy and minimize the loss.

KOHN (1961) extensively reviewed the per ception of chemical stimulii in gastropods, docu menting mainly the response of sea carnivorous gastropods.

BOVBJERG (1968, 1975), studying the fee ding habits of limneides, suggests that the herbi vorous molluses of fresh water. because living in dense vegetation, do not suffer selection pres sure to identify food at a distance. Such a condi tion would favor a randomic finding of food, and recognition would be achieved by contact.

This interpretation was criticized by CROLL (1983), in a broader revision of the chem $i$ cal perception of gastropds, arguing that selec. tive advantages exist as much for the herbivorous as for the carnivorous in the spotting of food and shelter.

Work with Biomphalaria glabrata shows that it presents positive responses to extracts of the plants (MICHELSON, 1960; ETGES \& FRICK, 1966; TOWNSEND, 1973a,b; BOUS FIELD, 19791.

This work aimed at verifying whether B. te. nagophila presents attraction for extracts of ma crophytes, through their periphyton or whether the attraction differs among different kinds of macrophytes and among the periphytons.

\section{MATERIAL AND ME'THODS}

Six of the commonest macrophytes found where the molluscs were collected from ichacara Santo António - Núcleo Bandeirantes DF) were

(1) Instituto de Ciências Biológicas da Universidade Federal de Minas Gerais. Departamento de Biologia Geral. Caixa Postal 2486. CEP 30161 Belo Horizonte, Minas Gerais. Brasil. 
SANTOS, M. B. L. dos \& FREITAS. J. R. de - Preference of Biomphalaria tenagophila among macrophytes and their periphytons determined through the degree of attractiveness.. Rev. Inst. Med. trop. São Paulo, 30 (4): 264-269, 1988 .

used as baits, that is, Echinochloa crusgalli, Heteranthera reniformes, Commelina sp., Nasturtium pumilum, Hydrocotyle ranunculoides, and Polygonum acre. Twenty grammes of leaves fresh weight of each adult macropnyte without a periphyton was liquified with $150 \mathrm{ml}$ of distilled water. Then the extract was sieved for separating the fibers, and the solution was mixed in $10 \mathrm{ml}$ with $12 \mathrm{~g}$ of colorless flavorless jelly. The solution was stored in shallow glass container for 24 hours for solidification. Then the solidified material was cut up into tablets $(3.5 \mathrm{~cm} \times 3.5$ $\mathrm{cm} \times 0.7 \mathrm{~cm}$ ).

For control, only jelly tablets were used 12 $\mathrm{g}$ of jelly in $250 \mathrm{ml}$ of distilled water. When the bait used was the periphyton of macrophytes, a volume of $30 \mathrm{ml}$ of periphyton prepared in jelly tablets as described above for macrophytes was used.

The experiments were conducted in square aluminium trays $(52 \times 52 \times 4.5 \mathrm{~cm})$. The bottom of the container was divided in pencil into four parts. Each part was subdivided into four parts and in each part the position of the baits was determined. The baits were laid out in circles, equally distant from the center of the container of $15 \mathrm{~cm}$ (Fig. 1). For each group of baits tested at least three repetitions were carried out, alternating the sequence of the baits in such a way that each bait remained next to a certain kind of bait twice and once farther from this same kind of bait. The change of sequence of the ex tracts was made to prevent a constant proximity of two baits from affecting the results, whether the baits be mutually attractive or repellent.

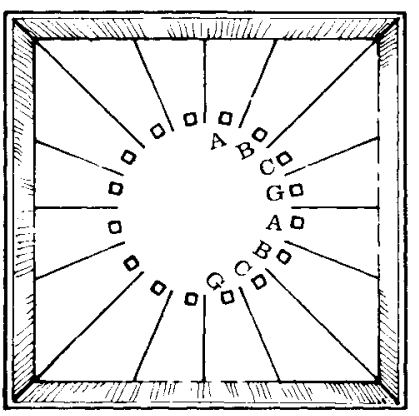

Sequence ABCG

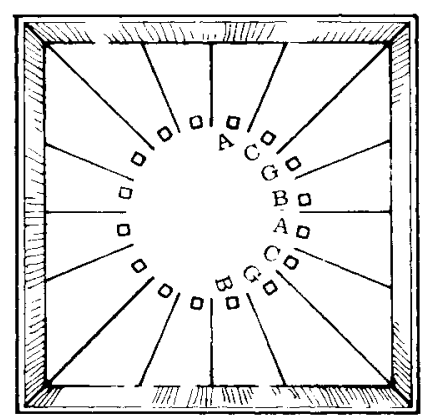

Sequence ACGB

$\square$ position of baits

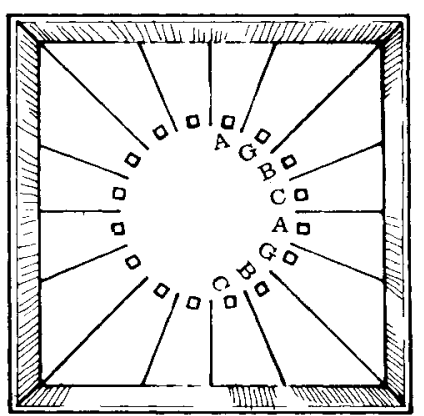

Sequence AGBC

A,B,C and G - refer to the kind of baits used in set 1 (see Table 1)

Fig. 1 - Scheme of the sets of experiments, with the model of the container used, location and sequence of baits.

The molluscs were released at the center of the circle of baits in the experiment - container after one hour without any given food. Melanic molluscs having a shell diameter ranging from 9 to $15 \mathrm{~mm}$ were used, collected from the study area. The molluses were not repeated in the ex periments of a same set.

The different set of experiments conducted had the following characteristics:

Set 1- Attraction experiment using extracts of the following macrophytes: (A) Echinochloa crusgalli; (B) Heteranthera reniformis; (C) Commelina sp. and (G) Control.

Set 2 - Attraction experiment using extracts of the following macrophytes: (D) Nastur- tium pumilum; (E) Hydrocotyle ranunculoides; (F) Polygonum acre and (G) Control.

- Set 3 - Attraction experiment using the macrophytes which most attracted in sets 1 and 2 .

Set 4 - Attraction experiment using periphy ton extract blocks in jell of the following $\mathrm{ma}$ crophytes: (Dp) Nasturtium pumilum; (Ap) Echinochloa crusgalli; (Cp) Commelina $\mathrm{sp}$; (Fp) Polygonum acre.

\section{Data collection and analysis}

The molluscs were taken out of the cube soon after they got to the bait (macrophyte or periphyton extract) and the kind of bait which 
SANTOS, M. B. L. dos \& FREITAS. J. R. de - Preference of Biomphalaria tenagophila among macrophytes and their periphytons determined through the degree of attractiveness.. Rev. Inst. Med. trop. Sä Paulo, 30(4): 264269 . 1988

attracted, them as well as the place where it lay were written down.

This procedure was repeated every $15 \mathrm{minu}$ tes, during two and a half hours, ten times. After this period, the molluses which remained either in the center or on the way without scattering, were counted and the figure was written down. To this result was added the ones which had been attracted to each kind of bait the $x^{2}$ test was applied. Three liberty degrees were used when the four baits were compared, 2 degrees when the comparison was made among three baits and 1 degree when two baits were compa red. In all of these comparisons the significance level considered was $\mathrm{p}=0.05$. In each set the three bait sequence were tested with at least two repetitions each and with the average num ber of 80 molluses.

\section{RESULTS}

The molluscs responded positively to the sti mulus from the macrophyte extracts used and from the periphyton extracts.

The results of each set of measurement of B. tenagophila attraction are summarized in $\mathrm{Ta}$ ble 1 .

TABLE 1

Attraction of Biomphalaria tenagophila for baits of macrophytes extracts prepared in jelly blocks and bait of macrophyte periphytons Ho - Equality of the number of molluses to each kind of extract in each set

\begin{tabular}{|c|c|c|c|c|c|c|c|c|}
\hline Secs & & $\begin{array}{c}\text { Number of } \\
\text { molluscs attracted } \\
\text { to each bait }\end{array}$ & & & $x^{2}$ & & & $\begin{array}{l}\text { Attraction intensity } \\
\text { of molluscs for } \\
\text { the baits for each set }\end{array}$ \\
\hline \multirow{4}{*}{1} & A - Echinochloa crusgalli & 351 & \multirow{4}{*}{$\begin{array}{c}214,4 \\
(\mathrm{ABCG})\end{array}$} & \multirow{4}{*}{$\begin{array}{c}52,9 \\
(\mathrm{ABC})\end{array}$} & \multirow{4}{*}{$\begin{array}{c}41.3 \\
(A B)\end{array}$} & \multirow{4}{*}{$\begin{array}{l}\text { N.S } \\
\text { (AC) }\end{array}$} & \multirow{4}{*}{$\begin{array}{c}45,2 \\
(B C)\end{array}$} & \multirow{4}{*}{$\mathrm{C}=\mathrm{A}>\mathrm{B}>\mathrm{G}$} \\
\hline & B - Heteranthera reniformis & 200 & & & & & & \\
\hline & $\mathrm{C}$ - Commelina sp. & 359 & & & & & & \\
\hline & $G-$ Control & 81 & & & & & & \\
\hline \multirow{4}{*}{2} & D - Nasturtium pumilum & 191 & \multirow{4}{*}{$\begin{array}{c}79,1 \\
\text { (DEFG) }\end{array}$} & \multirow{4}{*}{$\begin{array}{c}31,2 \\
\text { (DEF) }\end{array}$} & \multirow{4}{*}{$\begin{array}{l}15.7 \\
\text { (DE) }\end{array}$} & \multirow{4}{*}{$\begin{array}{c}5.45 \\
\text { (EF) }\end{array}$} & \multirow{4}{*}{$\begin{array}{l}11.0 \\
(E F)\end{array}$} & \multirow{4}{*}{$\mathrm{D}>\mathrm{F}>\mathrm{E}>\mathrm{G}$} \\
\hline & E - Hydrocotyle ranunculoides & 96 & & & & & & \\
\hline & F - Polygonum acre & 148 & & & & & & \\
\hline & G- Control & 61 & & & & & & \\
\hline \multirow{4}{*}{3} & $\mathrm{D}$ - Nasturtium pumilum & 123 & \multirow{4}{*}{$\begin{array}{c}54.8 \\
(\mathrm{DACF})\end{array}$} & \multirow{4}{*}{$\begin{array}{c}5.8 \\
(D F)\end{array}$} & \multirow{4}{*}{$\begin{array}{l}13,1 \\
|\mathrm{AF}\rangle\end{array}$} & & & \\
\hline & A - Echinochloa crusgalli & 46 & & & & & & $\mathrm{D}>\mathrm{F}>\mathrm{A}=\mathrm{C}$ \\
\hline & C - Commelina sp. & 46 & & & & & & \\
\hline & F - Polygonum acre & 88 & & & & & & \\
\hline \multirow{4}{*}{4} & $\jmath p-$ Periphyton of N. Pumilum & 111 & \multirow{4}{*}{\multicolumn{2}{|c|}{$\begin{array}{l}\text { N.S. } \\
\text { (DpApCpFp) }\end{array}$}} & & & \multirow{4}{*}{\multicolumn{2}{|c|}{$D p=A p=C p=F p$}} \\
\hline & Ap - Periphyton of E. crusgalli & 117 & & & & & & \\
\hline & $\mathrm{Cp}$ - Periphyton of Commelina sp. & 111 & & & & & & \\
\hline & Fp -- Periphyton of P. acre & 127 & & & & & & \\
\hline
\end{tabular}

Meaningless at the level of $p=0.05$

The first set showed that there existed preference and through the frequency in the distribution of the molluscs in each bait, the following attraction sequence was established in this set: Commelina sp. extract $(C)$ had the same power of attraction as the Echinochloa crusgalli (A) which attracted more than the Heteranthera re niformis, (B), and all of them attracted more than the control $(G)$.
Set 2 - experiments were meaningful and the following order of preference was established, through the frequencies of the attracted molluscs: Nasturtium pumilum (D) attracted more than Polygonum acre (F), which attracted more than Hydrocotyle ranunculoides ( $E$ ), and the latter attracted more than the control.

In set 3 , the four macrophytes which attracted more in sets 1 and 2 were experimented toge- 
SANTOS, M. B. L. dos \& FREITAS, J. R. de - Preference of Biomphalaria tenagophila among macrophytes and their periphytons determined through the degree of attractiveness. Rev. Inst. Med. trop. São Paulo, 30 (4): $264-269$, 1988.

ther: D - Nasturtium pumilum, A - Echinoch. loa crusgalli, $\mathrm{C}$ - Commelina sp. and F-Polygonum acre. The combinations DACF and the combination AF were meaningful. Thus the following attraction order can be established: Nasturtium pumilum (D) attracted more than Polygonum acre $(F)$, which attracted more than Comelina sp. (C), which had the same power of attraction as Echinochloa crusgalli (A) D $>\mathrm{F}>\mathrm{A}$ $=\mathrm{C}$.

The experiments among the macrophyte periphyton were $D p$ - Peryphyton of Nasturtium pumilum Ap - Periphyton of Echinochloa crusgalli, Cp - Periphyton of Commelina sp., Fp - Periphyton of Poligonum acre. The molluscs were attracted to these baits but they did not show preferences among them.

\section{DISCUSSION}

In the present paper, the attraction of $\mathbf{B}$. tenagophila for macrophytes and periphyton was emphasized. It is assumed that this attraction is due to stimulii of chemical substances since there is no color discrimination among gastropodes. Their visual perception is limited to different light intensities (PURCHON, 1978): and since the extracts of the plants were used, their shape as a means of shelter was eliminated as an attraction factor.

Several hypothesis have been speculated to explain this attraction phenomenon, in the search for an understanding of both the mediating substance and the adaptive motive for the existence of the attraction. As for the kind of mediating substance, several studies have shown that water vegetables (macrophytes and algae) liberate in the environment, several organic compositions such as amino and imino-acids, small chains of carboxilic and hydroxiatic acids (MAKSIMOVA \& PIMENOVA, 1969; CHANG \& TOLBERT, 1970; WETZEL \& MANNY, 1972; JUT'PNER \& FRITZ, 1974; PATIENCE et al., 1983).

Studies with B.glabrata have demonstrated that this species is sensitive to the chemical stimulii of carboxilic acids and amino acids (THOMAS \& ASSEF, 1979; THOMAS et al., 1983). It was also emphasized by THOMAS et al., 1983. that the range of chemical perception is very similar among B. glabrata, B. straminea, Phy. sela acute, Helisoma duryi, Lymnaea natalensis and $\mathbf{L}$. stagnalis and justified by the similarities in the feeding habits of those species.

Assuming that B. glabrata and B. tenagophila are similar species, with geographical distribution overlapping in same areas, but without cohabitation in the same habitat, demonstrating that there is kind of competition between them, and that this is probably due to the great niche similarity, one can suppose that the attraction exerted by the macrophytes is due to the liberation of the same products, amino acid, imino acids and carboxilic acids already experimented as attractors to B. glabrata.

The difference of attraction among the ma crophytes could be linked to a qualitative effect, that is each one would liberate a kind of substance that would have greater or lesser attraction power. We should also take into account the possibility of occurrence of antagonist substances, of a effect detected by BOUSFIELD (1979), which diminish the response of B.glabrata to Apium nodiflorum (Umbelliferae) and Roripa nasturtium aquaticum (Cruciferae) accor ding to the increase in concentration. Extracts of these plants mixed with wheat germ extract which have great attraction power, diminishes its capacity to stimulate the responses of the molluses to approach the plants or rather, if could just be the quantitative effect in which the attracting substances liberated in greater or lesser concentration would attract the molluscs in different intensities.

In several studies, including the present, the attracting factors are chemical. Thus, the chemical studies of extracts and experiments for the verification of the behavior of the mollusc before isolated substances will be carried out for the confirmation of these hypothesis.

The hypothesis proposed to explain the reason for the attraction are:

1. Feeding - it has been observed that organic compositions liberated by water vegetables are assimilated by invertebrated (SEPERS. 1977). The importance of amino butiric acid, pro- 
SANTOS. M. B. L. dos \& FREITAS, J. R. de - Preference of Biomphalaria tenagophila among macrophytes and their periphytons determined through the degree of attractiveness.. Rev. Inst. Med. trop. Säo Paulo, 30(4): 264269. 1988

duced by the algae, in the induction of the metamorphosis in larvae, of Haliotis rufensis was ma de clear. It was also observed that the B. glabrata is capable of assimilating amino acids in solution, (GILBERTSON \& JONES, 1972) and iron GAZINELLI et al.. 1970). Thus the necessity of some organic compositions take out of the water to their metabolism could attract the molluses to the source of production, that is macrophytes and algae.

2. Symbiosis relationship with macrophy. tes - THOMAS (1982) and THOMAS \& TAIT (1984) have suggested a symbiosis relationship between macrophytes and molluscs. The cost of production and liberation of the organic com positions invested by the macrophytes would be compensated by the following benefits obtainable from the molluscs (a) getting rid of the periphytons. (b) increasing the nutrient circulation tax through fezes and dead mollusc. (c) $\mathrm{CO}_{2}$ and ammonia liberated by the molluses as excretion products would be used as nutrients by the plants. For the molluses there would be the following benefits: a) the macrophytes would protect the animals from factors like bright light and high temperature through their shade and water current; b) they would serve as laying sites: c) they are substracts to the periphyton development; $d$ ) they liberate $\mathrm{O}_{2}$ during the day, for the breathing of the molluscs; e) they remove ammonia and $\mathrm{CO}_{2}$, substances toxic to the molluses: f) they would function as shelter to prevent predation.

3. To avoid competition - the reason for attraction differences among plants, or difference in the chemical perception of each kind of macrophyte could be related to the necessity of avoiding competition with other species of molluscs PIP \& STEWART (1976) have verified that the maximum concentration of Physa gyrina and of the Potamogeton pectinatus coincides with the period in which hydrocarbons dilluted as fructose and glucose are at maximum concentration in the tissues of the plants. Pears of association of L. stagnalis with the plant Potamogeton richardsonii on the other hand, coincides with the period in which sacarose concentrations is at its maximum. The authors suggest that the molluscs are attracted for specific plants to prevent the inter-specific competition for food. As the B. tenagophyla is almost always associated to other kinds of molluscs like Physa and Lymnaea, and other periphyton eaters, such a hypothesis deserves verifying.

As the three hypothesis raised are not mutually exclusive, more detailed studies could verify the existence of all those forces acting in the adaptation process and in the co-evolution in the relationship between molluscs and macro. phytes.

As for the attraction exerted on the mo. lluscs, it can also be accounted for by the activity of chemical substances liberated by the algae. as it has been discussed for the macrophytes.

According to PORTER (1977) non-selective eating on the periphyton favors the coexistence of algae competing with less competitive ones. maintaing all of them in low density and preven ting the competitive exclusion among them.

Thus, we can suppose that the attraction of the periphyton on eating organisms is exerted by the algae or organisms with low competitive potential. Besides, the hipothesis of symbioses to account for the relationship mollusc $x$ periphyton, in spite of the predation suffered by the latter, is supported by the works of CALOW (1974) and HUNTER (1983), which demonstrated that the substance excreted by molluscs would serve as manure (Chiefly $P$ and $N$ ) to the periphy ton, increasing its production by up to $88 \%$.

All this adaptability explains in terms the success of this specie in water environment, mainly in small reservatories and irrigation canals.

In fact, this considerations become important to decide about this habitat management aiming the vector control, and also to rear these snails in laboratory.

\section{RESUMO}

Atração da Biomphalaria tenagophila por extratos de macrófitas

Em presença de extratos de seis macrófitas a Biomphalaria tenagophila apresentou maior 
SANTOS, M. B. L. dos \& FREITAS. J. R. de - Preference of Biomphalaria tenagophila among macrophytes and their periphytons determined through the degree of attractiveness.. Rev. Inst. Med. trop. Sáo Paulo, 30 (4): 264269. 1988 .

atraçāo por quatro delas, na seguinte ordem: Nasturtium pumilum $>$ Polygonum acre $>$ Commelina sp. = Echinocloa crusgalli. Para o perifíton destas macrófitas a B. tenagophila foi atraí da, sem mostrar preferência entre eles. Na discussào, tal comportamento é a valiado sob o ponto de vista da co-evoluçāo entre moluscos e plantas.

\section{REFERENCES}

1. BOUSFIELD, J. D. - Plant extracts and chemically trig gered positive rheotaxis in Biomphalaria glabrata (Say). snail intermediate host of Schistosoma mansoni iSam bon). J. appl. Ecol., 19: 681 690, 1979.

2. BOVBJERG, R. V. - Response to food in Lymnacid snails. Physiol. Zool., 41: 412-423, 1968

3. BOVBJERG, R. V. - Feeding and dispersal in the snail Stagnicola reflexa (Basommatophora: Lymnaeidae). Malacologia, 2: 199-207, 1975

4. CALOW, P. - Some observations on locomotory strate gies and their metabolic effects in two species of freshwater gastropods, Ancylus fluviatilis Müll and Planorbis contortus Linn. Oecologia, 16: 149-161, 1974 .

5. CHANG, W. H. \& TOLBERT, N. E. - Exeretion of glyco late, mesotartrate and isocitrate lactone by synchronized cultures of Ankistrodesmus braunii. Plant Physiol., 46: 377-385, 1970

6. CROLL. R. P. - Gastropod chemoreception. Biol. Rev. Camb. Philos. Soc., 58: 293 319. 1983

7. ETGES, F. J. \& FRICK, L. P. - An experimental field study of chemoreception and response in Australorbis glabratus (Say) under rheotactic conditions. Amer. J. trop. Med. Hyg., 15: 434-438, 1966

8. GAZZINELLI, G; RAMALHO-PINTO, F. J.: PELLEGRI NO, J. \& GILBERT, B. - Uptake of ${ }^{59} \mathrm{Fe}$ as a tool for the study of crowding effect in Biomphalaria glabrata. Amer. J. trop. Med. Hyg., 19: 1034. 1037, 1970

9. GILBERTSON, D. E. \& JONES, K. G. - Uptake and assimilation of amino-acids by Biomphalaria glabrata / $G$ as tropoda: Planorbidael Comp. Biochem. Physiol., 42A: $621 \cdot 626,1972$

i0. HUNTER, R. D. - Bioenergetic and community changes in intertidal aufwichs grazed by Littorina littorea. Ecology, 64: $761.769,1983$

11. JUTTNER, F. \& FRITZ, F. - Excretion produets of Ochromonas with special reference to pyrrolidone carboxylic acid. Arch. Microbiol., 96: 223-232, 1974
12. KOHN, A. J. - Chemoreception in gastropod molluses Amer. Zool., 1: 291 309. 1961

13. MAKSIMOVA. I. V. \& PIMENOVA. M. N. -- Liberation of organic acids by green unicellular algae Microbiology. 37: 6470.1969

14. MICHELSON, E. H. - Chemoreception in the snail Aus. tralorbis glabratus. Amer. J. trop. Med. Hyg., 9: 480487. 1960

15. PATIENCE, R. L.: STERRY, P. R. \& THOMAS. J. D. Changes in chemical composition of a decomposing aqua tic macrophyte, Lemna paucicostata. J. Chem. Ecol., 9: $889.911,1983$.

16. PIP, E \& STEWART. J. M. - The dynamic of two aquatic plant snail association. Canad. J. Zool., 54: 11921200. 1976.

17. PORTER, K. G. - The plant animal interface in fresh water ecosystems. Amer. Scient., 65: 159 170, 1977

18. PURCHON, R. D. - The biology of the Molusea. 2: ed. New York, Pergamon Press, 1978.

19. SEPERS. A. B. J. - The utilization of dissolved organic compounds in aquatic environments. Hydrobiologia, 52: 39-54. 1977.

20. THOMAS, J. D. \& ASSEF. B. -- Behavioural responses to amino acids by juvenile Biomphalaria glabrata, a snail host of Schistosoma mansoni. Comp. Biochem. Physiol., 63C: 99108,1979 .

21. Thomas, J. D. - Chemical ecology of the snail host of schistosomiasis: snail snail and snail plant interactions. Malacologia, 22: 81 91, 1982

22. THOMAS, J. D.: OFOSU BARKO. J. \& PATIENCE, R L. - Behavioural response to carboxylic and amino acids by Biomphalaria glabrata (Say) the snail host of Schistosoma mansoni (Sambon) and other freshwater molluses. Comp. Biochem. Physiol, 75C: 57 76, 1983.

23. THOMAS. J. D. \& TAIT, A. J. - Control of the snail hosts of schistosomiasis by environmental manipulation: a tield and laboratory appraisal in the IBADAN Area. Nigeria Phil. Trans. B, 305: 201-253, 1984.

24. TOWNSEND, C. R. - The food finding orientation mecha nism of Biomphalaria glabrata (Say). Anim. Behav., 21: 544-548. 1973a.

25. TOWNSEND, C. R. - The role of osphradium in chemore ception by the snail Biomphalaria glabrata (Say). Anim. Behav., 21: 549-556, 1973b

26. WETZEL, R. G. \& MANNY, B. A. - Secretion of dissolved organic nitrogen by aquatic macrophytes. Arch. Hidrobiol., 18: 162-170, 1972.

Recebido para publicaçáo em 10/12/1987 